\title{
Water Leakage and Nitrate Leaching Characteristics in the Winter Wheat-Summer Maize Rotation System in the North China Plain under Different Irrigation and Fertilization Management Practices
}

\author{
Shufeng Chen ${ }^{1,2}$, Chengchun Sun ${ }^{1}$, Wenliang $\mathrm{Wu}^{2, *}$ and Changhong Sun ${ }^{1}$ \\ 1 Beijing Municipal Research Institute of Environmental Protection, Beijing 100037, China; \\ shufengchen@163.com (S.C.); shandong.baozi@163.com (Che.S.); wuwl@cau.edu.cn (Cha.S.) \\ 2 College of Resources and Environmental Sciences, China Agricultural University, Beijing 100193, China \\ * Correspondence: wuwenl@cau.edu.cn; Tel.: +86-10-62732387
}

Academic Editor: Karim Abbaspour

Received: 16 October 2016; Accepted: 14 February 2017; Published: 22 February 2017

\begin{abstract}
Field experiments were carried out in Huantai County from 2006 to 2008 to evaluate the effects of different nitrogen $(\mathrm{N})$ fertilization and irrigation management practices on water leakage and nitrate leaching in the dominant wheat-maize rotation system in the North China Plain (NCP). Two $\mathrm{N}$ fertilization $\left(\mathrm{NF}_{1}\right.$, the traditional one; $\mathrm{NF}_{2}$, fertilization based on soil testing) and two irrigation $\left(\mathrm{IR}_{1}\right.$, the traditional one; $\mathrm{IR}_{2}$, irrigation based on real-time soil water content monitoring) management practices were designed in the experiments. Water and nitrate amounts leaving the soil layer at a depth of $2.0 \mathrm{~m}$ below the soil surface were calculated and compared. Results showed that the $\mathrm{IR}_{2}$ effectively reduced water leakage and nitrate leaching amounts in the two-year period, especially in the winter wheat season. Less than 10 percent irrigation water could be saved in a dry winter wheat season, but about 60 percent could be saved in a wet winter wheat season. Besides, 58.8 percent nitrate under single $\mathrm{NF}_{2} \mathrm{IR}_{1}$ and 85.2 percent under $\mathrm{NF}_{2} \mathrm{IR}_{2}$ could be prevented from leaching. The $\mathrm{IR}_{2}$ should be considered as the best management practice to save groundwater resources and prevent nitrate from leaching. The amounts of $\mathrm{N}$ input play a great role in affecting nitrate concentrations in the soil solutions in the winter wheat-summer maize rotation system. The $\mathrm{NF}_{2}$ significantly reduced $\mathrm{N}$ inputs and should be encouraged in ordinary agricultural production. Thus, nitrate leaching and groundwater contamination could be alleviated, but timely $\mathrm{N}$ supplement might be needed under high precipitation condition.
\end{abstract}

Keywords: water leakage; nitrate leaching; maize; winter wheat; optimized nitrogen fertilization; optimized irrigation

\section{Introduction}

The North China Plain (NCP) is a major grain-producing region in China with a long-term average annual precipitation of $550 \mathrm{~mm}$, most of which occurs from June to September, and an average yearly crop evapotranspiration of $850 \mathrm{~mm}$. To obtain higher grain yields, a large amount of fertilizer and water were supplied by farmers in this region. It was reported that the average annual amount of nitrate input was above $500 \mathrm{~kg} \mathrm{~N} \cdot \mathrm{ha}^{-1}$ in the NCP [1]. In some high-yielding farmlands, the input even reached as high as $600 \mathrm{~kg} \mathrm{~N} \cdot \mathrm{ha}^{-1}$ [2]. Farmers' traditional N fertilization practice usually causes high nitrate losses because of excessive $\mathrm{N}$ input. Research on field-scale $\mathrm{N}$ balances found that about $50 \%$ of $\mathrm{N}$ applied under traditional fertilization management practice was not accounted for by crop removal [3]. With excess surface water application, soluble nitrate can leach below the root zone to underlying groundwater, causing possible contamination of drinking water [4]. Excessive $\mathrm{N}$ 
input and inefficient application of irrigation water have caused heavy groundwater contamination in the NCP. Between the years 2002 and 2007, the nitrate concentration in shallow groundwater doubled [5]. Besides, a lack of surface water in this area led to the excessive extraction of groundwater for agricultural production, bringing about an annual $1.5 \mathrm{~m}$ drop in the groundwater level [6,7]. Water shortage and groundwater pollution have become important environmental concerns in the NCP. Improving water and $\mathrm{N}$ management in the farmland to reduce both groundwater exploitation and farmland nitrate leaching is of great importance to protect the groundwater resources.

Limited irrigation and reduced $\mathrm{N}$ application may be effective measures to reduce farmland nitrate leaching and to improve water and $\mathrm{N}$ use efficiencies. Reduction of the applied $\mathrm{N}$ fertilizer rate to an optimized rate can reduce soil nitrate leaching [8-10]. Nowadays, the optimized irrigation technique based on real-time monitoring of soil water content has been widely used in agricultural production and provides us an irrigation control measure [11]. It could attain the dual objectives of water-saving and high yield. Furthermore, the optimized $\mathrm{N}$ fertilization based on soil testing is a fertilization management practice that quantitatively supplies $\mathrm{N}$ fertilizer to ensure crop growth. It increases $\mathrm{N}$ use efficiencies of crops by a comprehensive consideration of available $\mathrm{N}$ in soil and crop $\mathrm{N}$ demand in different stages [11]. However, there have been few studies focused on the environmental effects of both the irrigation based on real-time monitoring of soil water content and the optimized $\mathrm{N}$ fertilization based on soil testing in the typical rotation system in the NCP so far.

The amounts of water leakage and nitrate leaching in the soil were the keys to analyze the effects of irrigation and fertilization management practices on nitrate leaching characteristics. Both water leakage and nitrate leaching were related to irrigation/precipitation, the rate and type of $\mathrm{N}$ fertilizer applied, the variety of crops, and other environmental factors. Major methods for direct measurement on water leaching amounts and nitrate leaching amounts include large lysimeter, leakage plate, tensiometers and so on [12-17]. Certainly, each method has its limitations and advantages. Currently, the method of using a tensiometer combined with Darcy's law [18] to determine the nitrate content in the soil solution has been extensively applied.

Huantai County, Shandong Province, China, is the first county reaching $1000 \mathrm{~kg} / \mathrm{ha}$ (wheat and maize) per year in the north Yangtze River. The winter wheat-summer maize rotation system is the basic cropping system in this region. To acquire a high crop yield, farmers depend heavily on the use of groundwater for irrigation in addition to a high $\mathrm{N}$ fertilizer application. Inadequate fresh irrigation supply in this region demands careful use and less contamination of all the available water resources. In this paper, both the water leakage and nitrate leaching amounts under different irrigation and fertilization management practices were obtained and analyzed. Results of this study would be useful to improve water and N fertilization management in the NCP to achieve a sustainable development of agriculture.

\section{Materials and Methods}

\subsection{Site Description}

Our experimental fields are located in Maojia Village of Xingcheng town, Huantai County (Figure 1). Experiment fields with relatively uniform soil types and hydrogeological conditions (groundwater level 15-20 m below soil surface) were chosen to ensure similar background. The experiments were carried out from to June 2006 to July 2007. Before this, a 1-year pre-trial from June 2005 to May 2006, the same as the formal experiment, had been conducted. During the experimental period, rainfall from June 2005 to May 2008 in the county was also collected (Figure 2). 


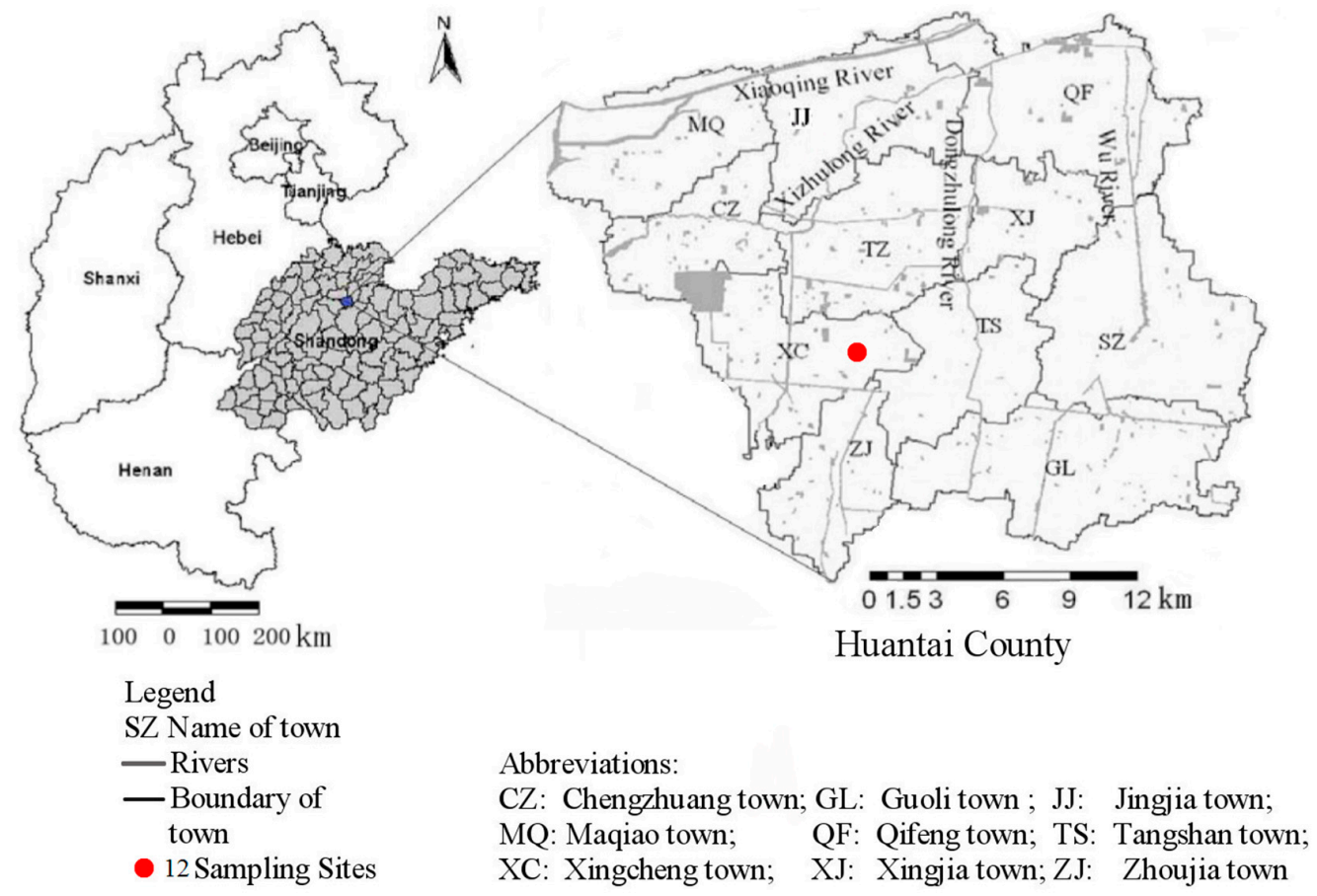

Figure 1. Location of the study area and the sampling sites.

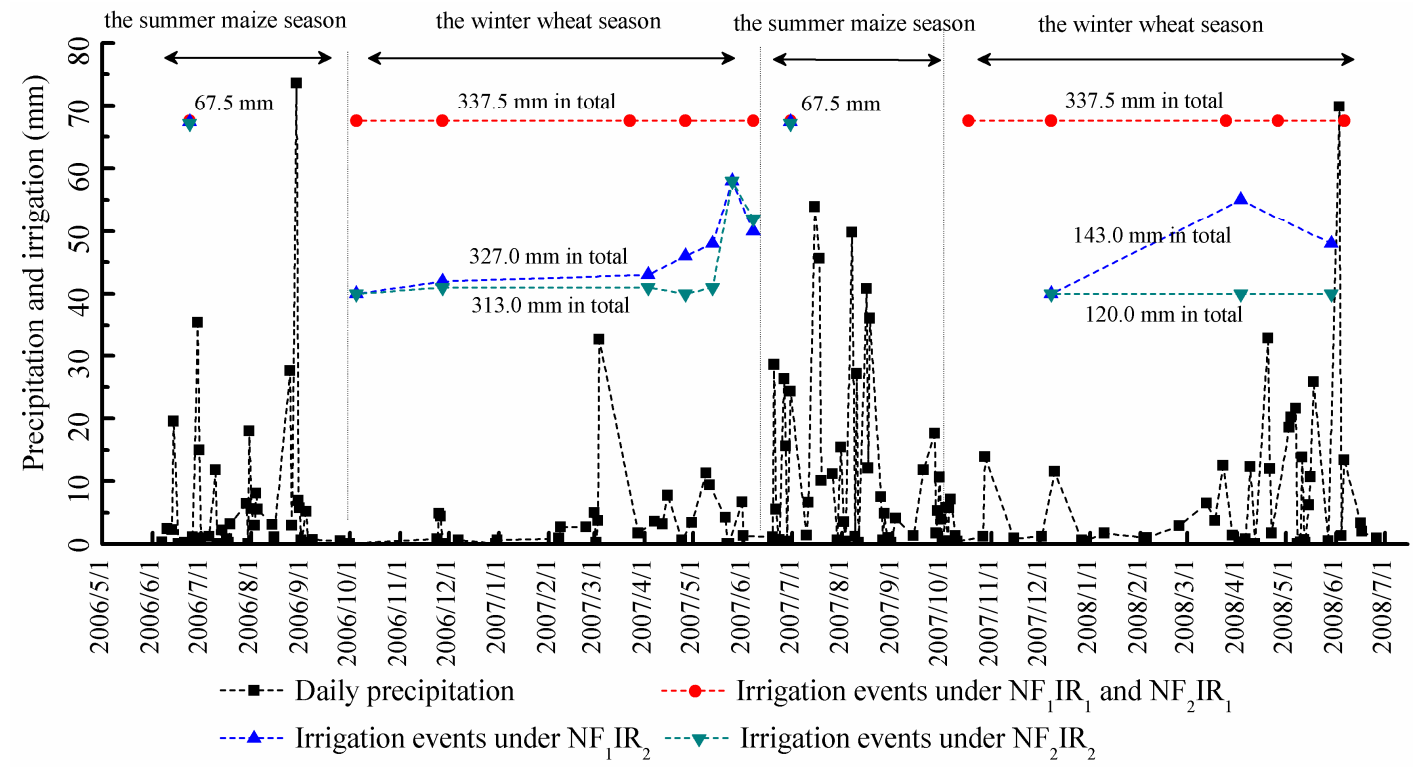

Figure 2. Daily rainfall and irrigation events from June 2005 to May 2008 in Huantai County.

\subsection{Experiment Design}

There were two irrigation management practices to meet the water requirements of the crops: the local traditional irrigation $\left(\mathrm{IR}_{1}\right)$ and the optimized irrigation $\left(\mathrm{IR}_{2}\right)$. Two fertilization management practices were also designed to meet the $\mathrm{N}$ requirements: the local traditional $\mathrm{N}$ fertilization $\left(\mathrm{NF}_{1}\right)$ and the optimized $\mathrm{N}$ fertilization $\left(\mathrm{NF}_{2}\right)$. A combination of the two factors $\left(\mathrm{NF}_{1} \mathrm{IR}_{1}, \mathrm{NF}_{2} \mathrm{IR}_{1}, \mathrm{NF}_{1} \mathrm{IR}_{2}\right.$, $\mathrm{NF}_{2} \mathrm{IR}_{2}$ ) were applied in 12 plots with three replicates.

The traditional irrigation management practice is a local famer's practice in the high-yielding winter wheat and summer maize system of the NCP. In this situation, irrigation events are usually arranged at the planting stage, before the over-wintering stage, at the regreening stage, at the shooting 
stage, and before the harvesting stage for winter wheat. Under the optimized irrigation management practice, sprinkler irrigation was used to keep plant-available soil water content (the difference in water content between measured field capacity and permanent wilting point in laboratory) between $40 \%$ and $85 \%$ according to the growth stages of the crop within defined soil depths [19]. Notably, because precipitation was relatively high and temporally even during the summer maize season, no extra irrigation is needed in our experiments. However, an irrigation event with $67.5 \mathrm{~mm}$ at the heading stage of summer maize under the two irrigation management practices was applied. The detailed irrigation dates and amounts during the winter wheat season are shown in Figure 2.

The traditional $\mathrm{N}$ fertilization management practice also represents a local farmer's practices in cropping. The traditional $\mathrm{N}$ fertilization management received $150 \mathrm{~kg} \mathrm{~N} \cdot \mathrm{ha}^{-1}$ (urea) at planting (incorporation after broadcasting) and another $150 \mathrm{~kg} \mathrm{~N} \cdot \mathrm{ha}^{-1}$ (urea) at the regreening stage (broadcast followed by irrigation) for winter wheat. As for summer maize, it received $100 \mathrm{~kg} \mathrm{~N} \cdot \mathrm{ha}{ }^{-1}$ (urea) as first topdressing fertilizer (broadcast followed by irrigation or before rain) at the three-leaf stage, shooting stage, and heading stage, respectively. The rate and time of $\mathrm{N}$ fertilization in the optimized $\mathrm{N}$ fertilization management practice was based on an improved $\mathrm{N}_{\text {min }}$ method, which considered the synchronization of crop nitrate demand and soil nitrate supply [11]. It is required to ensure the growth of crops in different growth stages. The rates of phosphorus and potassium fertilizer were the same in all the management practices, applied as basal fertilizer once before winter wheat is sown. The rate of phosphorus was $375 \mathrm{~kg} \mathrm{P}_{2} \mathrm{O}_{5} \cdot \mathrm{ha}^{-1}$, and potassium was $225 \mathrm{~kg} \mathrm{~K} \mathrm{~K}_{2} \mathrm{O} \mathrm{ha}^{-1}$. Detailed fertilization dates and rates are shown in Table 1.

Table 1. $\mathrm{N}$ fertilization dates and rates under different management practices.

\begin{tabular}{|c|c|c|c|c|c|c|}
\hline \multicolumn{2}{|c|}{ Items } & \multirow[t]{2}{*}{ Crop Stage } & \multicolumn{4}{|c|}{ Fertilizer Application Rate/kg N.ha ${ }^{-1}$} \\
\hline Season & Date & & $\mathrm{NF}_{1} \mathrm{IR}_{1}$ & $\mathbf{N F}_{2} \mathrm{IR}_{1}$ & $\mathrm{NF}_{1} \mathrm{IR}_{2}$ & $\mathrm{NF}_{2} \mathrm{IR}_{2}$ \\
\hline \multirow{4}{*}{$\begin{array}{c}2006, \\
\text { Summer maize }\end{array}$} & 2-June & three-leaf stage & 100 & & 100 & 38 \\
\hline & 28-June & shooting stage & 100 & 35 & 100 & \\
\hline & 23-July & heading stage & 100 & & 100 & 38 \\
\hline & Subtotal & & 300 & 35 & 300 & 38 \\
\hline \multirow{4}{*}{$\begin{array}{c}\text { 2006-2007, } \\
\text { Winter wheat }\end{array}$} & 5-October & planting stage & 150 & & 150 & \\
\hline & 20-March & regreening stage & 150 & 40 & 150 & 35 \\
\hline & 16-April & & & 22 & & 18 \\
\hline & Subtotal & & 300 & 62 & 300 & 53 \\
\hline \multirow{5}{*}{$\begin{array}{c}2007 \\
\text { Summer maize }\end{array}$} & 26-May & three-leaf stage & 100 & & 100 & \\
\hline & 9-June & & & 63 & & 57 \\
\hline & 26-June & shooting stage & 100 & & 100 & \\
\hline & 28-July & heading stage & 100 & & 100 & \\
\hline & Subtotal & & 300 & 63 & 300 & 57 \\
\hline \multirow{4}{*}{$\begin{array}{c}\text { 2007-2008, } \\
\text { Winter wheat }\end{array}$} & 16-October & planting stage & 150 & & 150 & \\
\hline & 20-March & regreening stage & 150 & 44 & 150 & 36 \\
\hline & 16-April & & & 30 & & 31 \\
\hline & Subtotal & & 300 & 74 & 300 & 67 \\
\hline \multicolumn{2}{|c|}{ Total } & & 1200 & 234 & 1200 & 215 \\
\hline
\end{tabular}

\subsection{Observation Items and Methods}

Water leakage and nitrate leaching amounts are main data needed to realize the analysis. Water and nitrate monitoring experiments combined with Darcy's Law [20] were combined to estimate the leaching amounts. Though requiring many parameters and less accuracy, this method is cost-saving and includes both upward and downward movement of water. It has obvious advantages in multi-treatment field experiments.

The tensiometer was used to obtain the soil water potentials (mm, sum of soil matrix and gravimetric potentials) in these experiments. Considering the root system of the crops, mainly 
distributed within a $2.0 \mathrm{~m}$ depth soil layer, the tensiometer installation depths in the soil profile were accordingly set at $1.8 \mathrm{~m}$ and $2.0 \mathrm{~m}$ depth in each field. The soil volumetric water contents of soil layers $(0-2.0 \mathrm{~m})$ were measured by a neutron probe (calibrated for about ten times at the beginning of the experiments) at $20 \mathrm{~cm}$ intervals. Both the soil volumetric water contents and tensiometer readings were recorded once a week. The soil water storage ( 0 to $2.0 \mathrm{~m}$ depth) of the experimental sites was calculated based on soil volumetric water content and layers of soil thickness; the thickness of each layer of soil in our study was $0.20 \mathrm{~m}$. Field water capacity was calculated from the average profile water content for two 3-day periods just after irrigation or significant rainfall in summer. In this paper, it is $54.3 \mathrm{~mm}$.

Suction cups (i.e., soil solution samplers) were installed at $2.0 \mathrm{~m}$ depth below the soil surface to obtain soil solutions. The soil solutions were collected biweekly. A portable vacuum pump was applied up to $80 \mathrm{kPa}$ suction for $24 \mathrm{~h}$ to collect all solutions in the suction cups. When the soil was too dry to collect samples, soil samples were collected instead and extracted with $0.01 \mathrm{M} \mathrm{CaCl}_{2}$ solution. Nitrate concentrations of all the soil solutions were determined by a continuous flow analytical system (TRAACS 2000 system, Bran and Luebbe, Norderstedt, Germany). Water from both precipitation and irrigation events was also sampled to determine nitrate concentrations, and then multiplied by water amounts to obtain the nitrate input to the soil.

Meteorological data such as precipitation were obtained from an automatic weather station of the local water conservancy bureau. In winter, observations of both water leakage and nitrate leaching were suspended because of freezing.

Water leakage amount at the $2.0 \mathrm{~m}$ depth of the soil profile was calculated by Darcy's Law combined with the Van Genuchten model [20-22]. The Van Genuchten model was used to obtain the parameters in the soil water characteristic curve. The obtained parameters were needed to determine $K(h)$. Then, $K(h)$ was used in Darcy's Law, which was used to calculate the water transport. The formulas are listed as follows:

$$
\begin{gathered}
q_{200}(t)=K(h) \times\left(H_{180}(t)-H_{200}(t)\right) / \Delta H, \\
\left\{\begin{array}{c}
\theta(h)=\theta_{r}+\frac{\theta_{s}-\theta_{r}}{\left[1+|a h|^{n}\right]^{m}}, \text { when } h<0 \\
\theta(h)=\theta_{s} \quad, \text { when } h=0
\end{array}\right. \\
K(h)=K_{s}\left(\frac{\theta-\theta_{r}}{\theta_{s}-\theta}\right)^{l}\left[1-\left(1-\left(\frac{\theta-\theta_{r}}{\theta_{s}-\theta}\right)^{1 / m}\right)^{m}\right]^{2}
\end{gathered}
$$

where $q_{200}(t)$ is the water leakage amount at $2.0 \mathrm{~m}$ depth of the soil profile during $t\left(\mathrm{~mm} \cdot \mathrm{day}^{-1}\right)$; $K(h)$ is the hydraulic conductivity $\left(\mathrm{mm} \cdot \mathrm{day}^{-1}\right) ; h$ is the matrix potential $(\mathrm{mm})$ measured once a week; $H_{180}(t)$ and $H_{200}(t)$ are soil water potentials $(\mathrm{mm})$ at $1.8 \mathrm{~m}$ and $2.0 \mathrm{~m}$ depth of the soil profile during $t$ (measured once a week in this paper), respectively; $t$ is the measurement period ( 7 days here); $\Delta H$ is the distance between the $1.8 \mathrm{~m}$ and $2.0 \mathrm{~m}$ depths $(\mathrm{mm}) ; \theta_{s}, \theta_{r}$, and $\theta(h)$ are saturated, residual, and measured soil volumetric water content, respectively $(\%) ; \theta_{r}, \theta_{s}, \alpha, m, n, l$ are parameters of the soil water characteristic curve (analyzed by the Van Genuchten model). The soil layer at $1.6 \mathrm{~m}$ to $2.0 \mathrm{~m}$ depth was chosen, and finally, these parameters were found to be $0.11,0.39,0.059,0.324,1.48$, and 0.5 , respectively; $K_{S}$ is the saturated hydraulic conductivity $\left(24.6 \mathrm{~mm} \cdot\right.$ day $^{-1}$, measured in laboratory by the constant head method [23].

$$
Q(T)=\int_{0}^{T} q_{200}(t) d t
$$

where $Q(T)$ is the water leakage amount at $2.0 \mathrm{~m}$ depth of the soil during a period $T(\mathrm{~mm}) ; T$ is the measurement cycle (days, growth season of winter wheat or summer maize in this paper).

Nitrate leaching amounts were calculated as the product of the nitrate concentrations and the corresponding $Q(T)$ through the $2.0 \mathrm{~m}$ depth soil profile as follows: 


$$
N(T)=\int_{0}^{T} C(t) q_{200}(t) / 100 d t
$$

Duncan's multiple range test was used to determine significant differences in means of water leakages and nitrate leaching amounts among the four management practices [24]. It is a method of multiple comparisons in which the group means are ranked from smallest to largest ( $a, b, c$, etc.).

\section{Results}

\subsection{Water Leakage at $2.0 \mathrm{~m}$ Depth}

In the summer maize growth season of 2006, no severe water leakage occurred at $2.0 \mathrm{~m}$ depth of the soil under the traditional and the optimized fertilization management practice (Figure 3a). The precipitation during the whole summer maize growth season of 2006 was temporally evenly distributed and about $200 \mathrm{~mm}$ less than the average annual precipitation (1962-2007) (Figure 4). Under all the management practices, the soil water storage in $2.0 \mathrm{~m}$ soil depth soil was, most of the time, lower than the field capacity (Figure 3b). The precipitation could only meet the requirement of summer maize growth. Only minor water leakage occurred in the period from August to September in 2006 (Figure 3a).

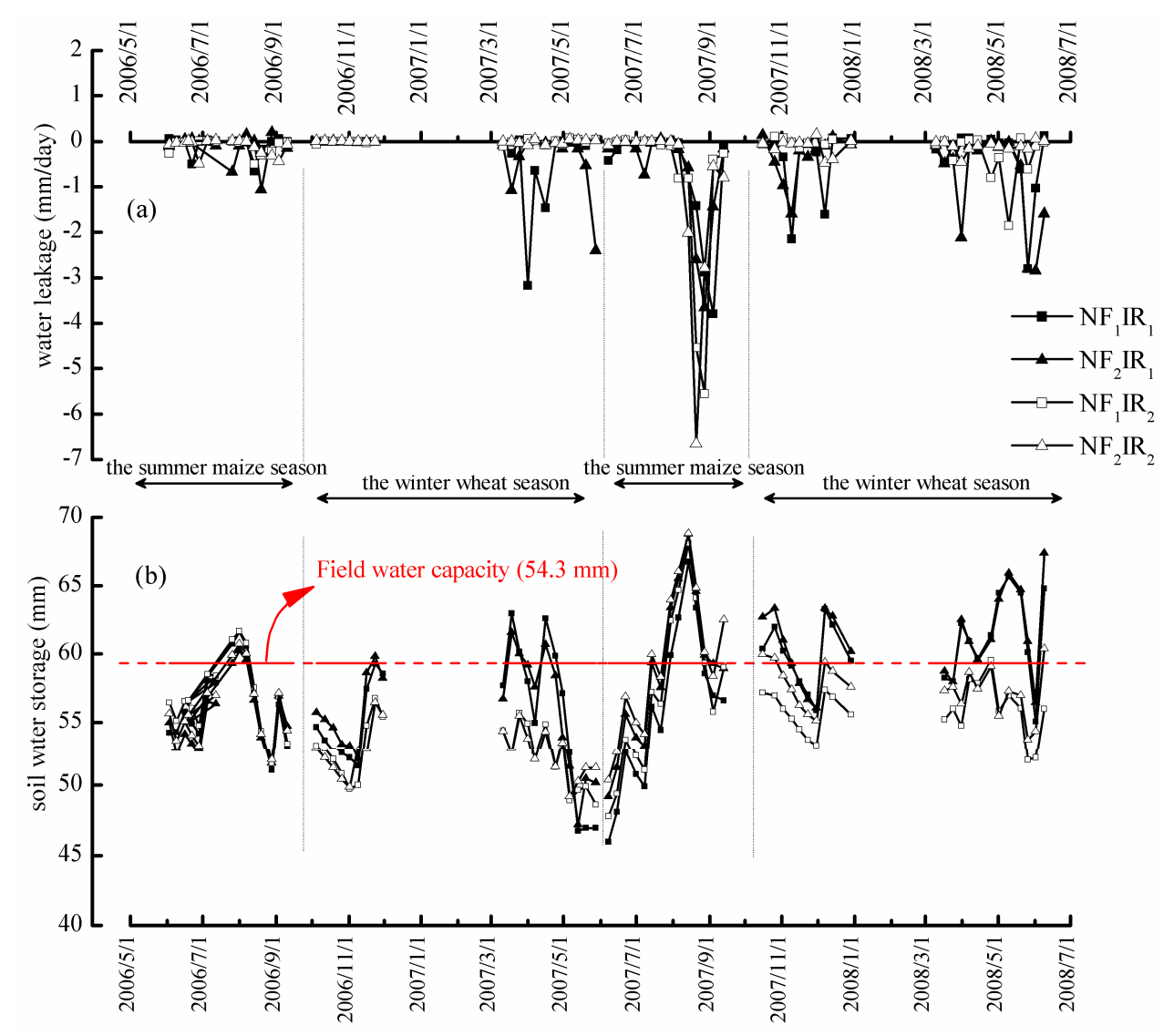

Figure 3. Water leakage and soil water storage (a) water leakage at a depth of $2.0 \mathrm{~m}$ under different fertilizer and irrigation management practices; (b) soil water storage in the 0-2.0 $\mathrm{m}$ soil profile.

During the winter wheat growth season of 2006-2007, due to the drought in the past summer maize season, no water leakage occurred in winter (Figure 3a). In the spring of 2007, no water leakage occurred under the $\mathrm{IR}_{2}$ management practices, but water leakages were observed under the $\mathrm{IR}_{1}$ management practices (Figure 3a). Furthermore, the amounts were $39.5 \mathrm{~mm}$ under $\mathrm{NF}_{1}$ and 
$52.1 \mathrm{~mm}$ under $\mathrm{NF}_{2}$ management practice, respectively (Table 2). The corresponding leakage rates (leakage/(irrigation + precipitation), the same below) were $8.8 \%$ and $11.6 \%$, respectively, which showed significant difference. The data indicated that even under the drought condition in the previous summer maize growth season, the traditional irrigation could still lead to farmland water leakage in the next winter wheat growth season. The traditional irrigation events in the spring of 2007 and the relatively higher precipitation in March (Figure 4) resulted in rapid increased soil water storage (five irrigation events in Figure 2), which exceeded the field capacity, eventually leading to water leakage. However, under the $\mathrm{IR}_{2}$ management practice, the optimized irrigation amount prevented soil water storage from exceeding the field capacity, which could greatly reduce the risk of water leakage (Figure $3 b$ ). Although there was little difference in total irrigation amount between $\mathrm{IR}_{1}$ and $\mathrm{IR}_{2}$ (Table 2), small quantities in the high frequency (seven irrigation events in Figure 2) of $\mathrm{IR}_{2}$ can maintain the soil water content in a reasonable range, which might have reduced the possibility of water leakage into deeper soil layers. In addition, the more irrigation occurences, the more water evaporation loss might have happened during the irrigation process.

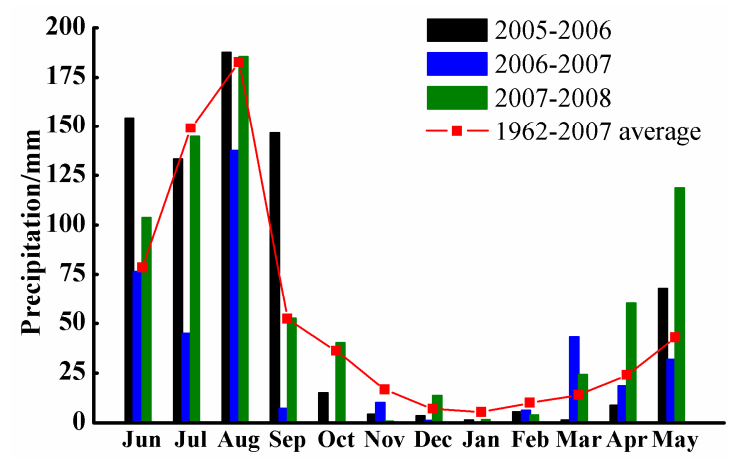

Figure 4. Monthly precipitation from June 2005 to May 2008 in Huantai County.

Table 2. Soil water balance under different irrigation and fertilizer management practices.

\begin{tabular}{|c|c|c|c|c|c|}
\hline \multicolumn{2}{|c|}{ Management Practices } & \multirow{2}{*}{$\frac{\mathbf{N F}_{\mathbf{1}} \mathbf{I R}_{\mathbf{1}}}{266.1}$} & \multirow{2}{*}{$\frac{\mathbf{N F}_{\mathbf{2}} \mathbf{I R}_{\mathbf{1}}}{266.1}$} & \multirow{2}{*}{$\begin{array}{c}\mathbf{N F}_{\mathbf{1}} \mathbf{I R}_{\mathbf{2}} \\
266.1\end{array}$} & \multirow{2}{*}{$\begin{array}{c}\mathbf{N F}_{\mathbf{2}} \mathbf{I R}_{\mathbf{2}} \\
266.1\end{array}$} \\
\hline \multirow{4}{*}{$\begin{array}{c}2006, \\
\text { Summer maize }\end{array}$} & Precipitation (mm) & & & & \\
\hline & Irrigation $(\mathrm{mm})$ & 67.5 & 67.5 & 67.5 & 67.5 \\
\hline & Water leakage amount (mm) & $8.1 \mathrm{~d}$ & $10.1 \mathrm{bc}$ & $9.2 \mathrm{c}$ & $11.8 \mathrm{a}$ \\
\hline & Water leakage rate $* / \%$ & 2.4 & 3.0 & 2.8 & 3.6 \\
\hline \multirow{4}{*}{$\begin{array}{c}\text { 2006-2007, } \\
\text { Winter wheat }\end{array}$} & Precipitation (mm) & 111.3 & 111.3 & 111.3 & 111.3 \\
\hline & Irrigation $(\mathrm{mm})$ & 337.5 & 337.5 & 327.0 & 313.0 \\
\hline & Water leakage amount (mm) & $39.5 b$ & $52.1 \mathrm{a}$ & 0 & 0 \\
\hline & Water leakage rate $/ \%$ & 8.8 & 11.6 & 0 & 0 \\
\hline \multirow{4}{*}{$\begin{array}{c}2007 \\
\text { Summer maize }\end{array}$} & Precipitation (mm) & 486.5 & 486.5 & 486.5 & 486.5 \\
\hline & Irrigation (mm) & 67.5 & 67.5 & 67.5 & 67.5 \\
\hline & Water leakage (mm) & $52.0 \mathrm{c}$ & $88.0 \mathrm{a}$ & $57.9 \mathrm{c}$ & $72.0 \mathrm{~b}$ \\
\hline & Water leakage rate $/ \%$ & 9.4 & 15.9 & 10.5 & 13.0 \\
\hline \multirow{4}{*}{$\begin{array}{c}\text { 2007-2008, } \\
\text { Winter wheat }\end{array}$} & Precipitation (mm) & 322.6 & 322.6 & 322.6 & 322.6 \\
\hline & Irrigation $(\mathrm{mm})$ & 337.5 & 337.5 & 143.0 & 120.0 \\
\hline & Water leakage (mm) & $106.0 \mathrm{~b}$ & $134.1 \mathrm{a}$ & $37.1 \mathrm{~d}$ & $61.1 \mathrm{c}$ \\
\hline & Water leakage rate $/ \%$ & 16.1 & 20.3 & 8.0 & 13.8 \\
\hline \multicolumn{2}{|c|}{ Total water leakage amount (mm) } & $205.6 b$ & $284.0 \mathrm{a}$ & $104.2 \mathrm{~d}$ & $145.2 \mathrm{c}$ \\
\hline \multicolumn{2}{|c|}{ Total water leakage rate/\% } & 10.3 & 14.2 & 5.8 & 8.3 \\
\hline
\end{tabular}

Notes: data in the same line with a same letter means no significant difference in means according to Duncan's multiple range test $(p<0.05) ;{ }^{*}$ presents the percent of water leakage that accounts for the sum of precipitation and irrigation. 
In the summer maize growth season of 2007, precipitation of $434.1 \mathrm{~mm}$ from June to August had led to the continuously increased soil water storage (Figure 3b). Also, heavy water leakages were observed. Total water leakages were $52.0 \mathrm{~mm}, 88.0 \mathrm{~mm}, 57.9 \mathrm{~mm}$ and $72.0 \mathrm{~mm}$ under $\mathrm{NF}_{1} \mathrm{IR}_{1}, \mathrm{NF}_{2} \mathrm{IR}_{1}$, $\mathrm{NF}_{1} \mathrm{IR}_{2}$ and $\mathrm{NF}_{2} \mathrm{IR}_{2}$, respectively, and the corresponding water leakage rates were $9.4 \%, 15.9 \%, 10.5 \%$ and $13.0 \%$ (Table 2). Under the same irrigation management practice, water leakages under $\mathrm{NF}_{2}$ management practice were obviously higher than those under $\mathrm{NF}_{1}$ management practice. Nutrient leaching due to frequent rainfalls and untimely topdressing under $\mathrm{NF}_{2}$ management practice might have a negative effect on crop growth, thus more water leakage occurred. During the winter wheat growth season of 2007-2008, excessive precipitation (Figures 2 and 4) caused severe water leakage (Figure 3a). The water leakages were 106.0, 134.1, 37.1 and $61.1 \mathrm{~mm}$ under $\mathrm{NF}_{1} \mathrm{IR}_{1}, \mathrm{NF}_{2} \mathrm{IR}_{1}, \mathrm{NF}_{1} \mathrm{IR}_{2}$ and $\mathrm{NF}_{2} \mathrm{IR}_{2}$, respectively. Furthermore, the corresponding leakage rates were $9.4 \%, 15.9 \%, 10.5 \%$ and $13.0 \%$, respectively (Table 2 ).

Under the same fertilization management practice, the water leakages under $\mathrm{IR}_{2}$ were significantly less than those under $\mathrm{IR}_{1}$ (Table 2), illustrating that the optimized irrigation could sharply reduce water leakage. Under the same irrigation management practice, water leakage under $\mathrm{NF}_{1}$ was less than that under $\mathrm{NF}_{2}$ (Table 2). During this season, the precipitation was $107.0 \mathrm{~mm}$ higher than the average annual value (Figure 4). Thus, water was adequate for wheat growth, and nutrient supply had become one of the key factors for the wheat growth. Furthermore, the $\mathrm{NF}_{1}$ provided more adequate $\mathrm{N}$ fertilizer for wheat growth, and then increased the water consumption and reduced the risk of water leakage.

Besides, under $\mathrm{IR}_{1}$, water leakage mainly occurred before the wintering, the regreening, and the harvesting stages, especially at the harvesting stage (Figure 3a). Under the rich precipitation conditions, the soil water storage often exceeded the field water capacity (Figure $3 b$ ), directly resulting in the water leakages. Under $\mathrm{IR}_{2}$, the irrigation amounts were 143.0 and $120.0 \mathrm{~mm}$ under $\mathrm{NF}_{1} \mathrm{IR}_{2}$ and $\mathrm{NF}_{2} \mathrm{IR}_{2}$, respectively. The soil water storage rarely exceeded the field water capacity, which greatly reduced the risk of water leakage occurring (Figure $3 b$ ).

During four crop growth seasons over two years, the total water leakages were 205.6, 284.0, 104.2 , and $145.2 \mathrm{~mm}$ and the total water leakage rates were $10.3 \%, 14.2 \%, 5.8 \%$ and $8.3 \%$ under $\mathrm{NF}_{1} \mathrm{IR}_{1}, \mathrm{NF}_{2} \mathrm{IR}_{1}, \mathrm{NF}_{1} \mathrm{IR}_{2}, \mathrm{NF}_{2} \mathrm{IR}_{2}$ management practices, respectively (Table 2). There was a significant difference between any two management practices.

\subsection{Nitrate Concentrations of the Soil Solutions at a Depth of $2.0 \mathrm{~m}$}

Table 1 showed that $\mathrm{NF}_{2}$ significantly reduced $\mathrm{N}$ inputs. Due to the 1-year pre-trial and less $\mathrm{N}$ inputs of the $\mathrm{NF}_{2}$ management practice, the nitrate concentrations of the soil solutions at a depth of $2.0 \mathrm{~m}$ in the four crop growth seasons were obviously lower than those under $\mathrm{NF}_{1}$ (Figure 5). It should be noticed that the nitrate concentrations under both $\mathrm{NF}_{2} \mathrm{IR}_{1}$ and $\mathrm{NF}_{2} \mathrm{IR}_{2}$ management practices had shown a decreasing trend from 2006 to 2008 , while the two under $\mathrm{NF}_{1} \mathrm{IR}_{1}$ and $\mathrm{NF}_{1} \mathrm{IR}_{2}$ tended to increase. Under the $\mathrm{NF}_{2}$, the groundwater may face less nitrate contamination risk. Under the same $\mathrm{NF}_{1}$ or $\mathrm{NF}_{2}$ management practices, the nitrate concentrations of $\mathrm{IR}_{2}$ were higher than those under $\mathrm{IR}_{1}$ management, suggesting that higher water input under $\mathrm{IR}_{1}$ might have diluted nitrate concentrations.

During the whole winter wheat and summer maize season from 2006 to 2007, less precipitation (Figure 2) and only minor water leakage (Figure 3a) indicated that both $\mathrm{N}$ fertilization and the irrigation management practices had no obvious effect on nitrate concentration changes. Nitrate concentrations contained a stable level in the four management practices, respectively.

In July and August of 2007 in the summer maize season, heavy water leakage occurred (Figure 3a) and nitrate concentrations of $\mathrm{NF}_{1} \mathrm{IR}_{1}$ and $\mathrm{NF}_{1} \mathrm{IR}_{2}$ increased sharply at a maximum of 114 and $121 \mathrm{mg} \mathrm{N} \cdot \mathrm{L}^{-1}$, respectively (Figure 5). The $434.1 \mathrm{~mm}$ precipitation from June to August in 2007 (Figure 2) led to soil water storage that was higher than the field water capacity (Figure 3b). The nitrate in the soil moved from the upper soil layer down to the $2.0 \mathrm{~m}$ profile along with the water movement. However, under the $\mathrm{NF}_{2}$, nitrate concentrations of both $\mathrm{NF}_{2} \mathrm{IR}_{1}$ and $\mathrm{NF}_{2} \mathrm{IR}_{2}$ were at a lower level, ranging from $27-37 \mathrm{mg} \mathrm{N} \cdot \mathrm{L}^{-1}$ to $31-42 \mathrm{mg} \mathrm{N} \cdot \mathrm{L}^{-1}$, respectively (Figure 5). 
During the winter wheat season from 2007 to 2008, nitrate concentrations of $\mathrm{NF}_{2} \mathrm{IR}_{2}$ hovered between 18 and $28 \mathrm{mg} \cdot \mathrm{L}^{-1}$ and those of $\mathrm{NF}_{2} \mathrm{IR}_{1}$ between 21 and $33 \mathrm{mg} \cdot \mathrm{L}^{-1}$ (Figure 5). Nitrate concentrations under $\mathrm{NF}_{2}$ were only about one-third of those under $\mathrm{NF}_{1}$. This showed that nitrate contents at the $2.0 \mathrm{~m}$ depth of the soil profile under the optimized nitrate fertilization were effectively controlled, though the values still exceeded the drinking water standard in China ( $\left.20 \mathrm{mg} \mathrm{N} \cdot \mathrm{L}^{-1}\right)$.

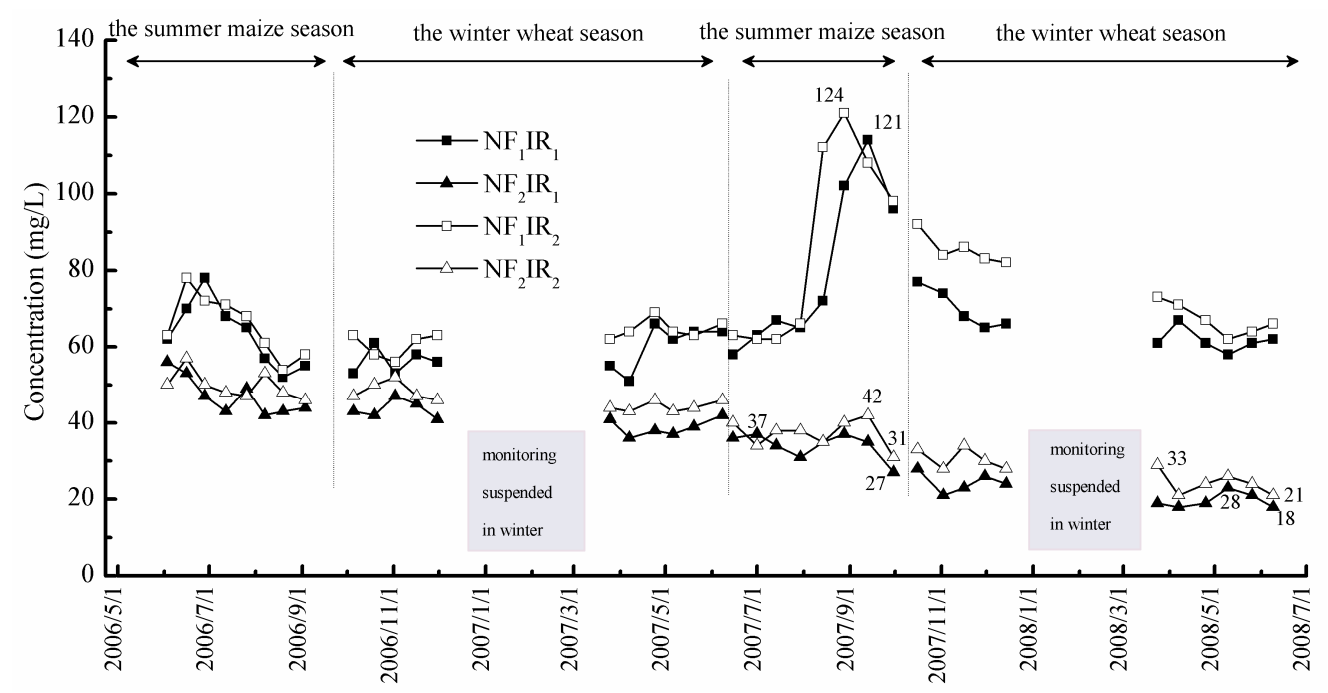

Figure 5. Nitrate concentrations of soil solutions at a depth of $2.0 \mathrm{~m}$ under different $\mathrm{N}$ and irrigation management practices.

\subsection{Nitrate Leaching Amounts from the Soil Profile at a Depth of $2.0 \mathrm{~m}$}

From 2006 to 2007, during the maize season, minor nitrate leaching occurred in all the four management practices (Figure 6 and Table 3). During the following winter wheat growth season, minor nitrate leaching occurred under $\mathrm{NF}_{1} \mathrm{IR}_{1}$ and $\mathrm{NF}_{2} \mathrm{IR}_{1}$, and the nitrate leaching amounts were 23.0 and $24.0 \mathrm{~kg} \mathrm{~N} \cdot \mathrm{ha}^{-1}$, respectively (Table 3). Almost no nitrate leaching was observed under $\mathrm{NF}_{1} \mathrm{IR}_{2}$ and $\mathrm{NF}_{2} \mathrm{IR}_{2}$. Because water movement is the driving force of nitrate leaching, the lower amount of water leakage (Figure $3 a$ ) under $I_{2}$ effectively minimized nitrate leaching in this season.

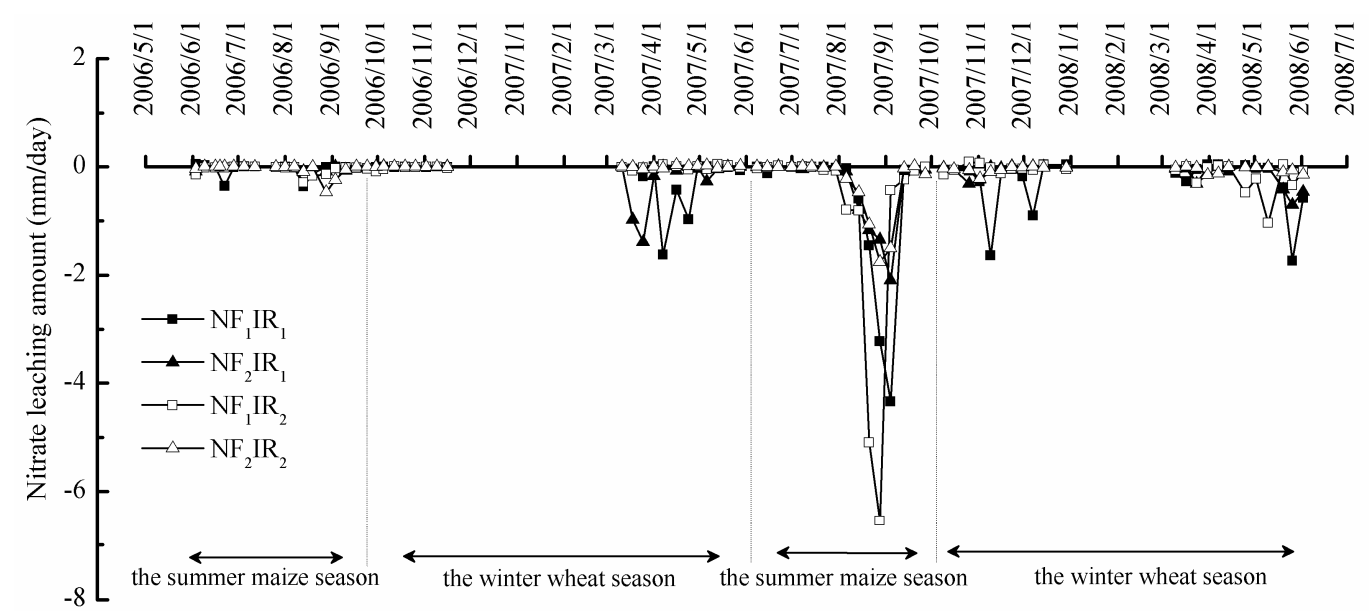

Figure 6. Nitrate leaching amounts under different $\mathrm{N}$ and irrigation management practices during the experiment. Negative values are represented by moving downward only. 
Table 3. Summary of nitrate inputs from rainfall, irrigation water and $\mathrm{N}$ fertilizer applied, and nitrate leaching in both wheat-maize cropping years.

\begin{tabular}{|c|c|c|c|c|c|c|}
\hline \multicolumn{2}{|c|}{ Items } & \multirow{5}{*}{$\begin{array}{c}\text { Management Practices } \\
\text { from fertilization } \\
\text { from precipitation } \\
\text { from irrigation } \\
\text { Total }\end{array}$} & \multirow{2}{*}{$\begin{array}{c}\mathbf{N F}_{\mathbf{1}} \mathbf{I R}_{\mathbf{1}} \\
300.0\end{array}$} & \multirow{2}{*}{$\begin{array}{c}\mathbf{N F}_{\mathbf{2}} \mathbf{I R}_{\mathbf{1}} \\
35.0\end{array}$} & \multirow{2}{*}{$\begin{array}{c}\mathbf{N F}_{\mathbf{1}} \mathbf{I R}_{\mathbf{2}} \\
300.0\end{array}$} & \multirow{2}{*}{$\begin{array}{c}\mathbf{N F}_{\mathbf{2}} \mathbf{I R}_{\mathbf{2}} \\
38.0\end{array}$} \\
\hline \multirow{6}{*}{$\begin{array}{l}2006, \\
\text { Summer maize season }\end{array}$} & \multirow{4}{*}{ Nitrate input $/ \mathrm{kg} \mathrm{N} \cdot \mathrm{ha}^{-1}$} & & & & & \\
\hline & & & 5.2 & 5.2 & 5.2 & 5.2 \\
\hline & & & 4.8 & 4.8 & 4.8 & 4.8 \\
\hline & & & 310.0 & 45.0 & 310.0 & 48.0 \\
\hline & \multirow{2}{*}{\multicolumn{2}{|c|}{$\begin{array}{l}\text { Leaching amount } / \mathrm{kg} \mathrm{N} \cdot \mathrm{ha}^{-1} \\
\quad \text { Nitrate leaching rate } / \%\end{array}$}} & $4.6 \mathrm{a}$ & $5.3 \mathrm{a}$ & $5.4 \mathrm{a}$ & $5.6 \mathrm{a}$ \\
\hline & & & 1.5 & 11.8 & 1.7 & 11.6 \\
\hline \multirow{6}{*}{$\begin{array}{l}\text { 2006-2007, } \\
\text { winter wheat season }\end{array}$} & \multirow{4}{*}{ Nitrate input $/ \mathrm{kg} N \cdot \mathrm{ha}^{-1}$} & from fertilization & 300.0 & 62.0 & 300.0 & 53.0 \\
\hline & & from precipitation & 2.5 & 2.5 & 2.5 & 2.5 \\
\hline & & from irrigation & 21.1 & 21.1 & 20.1 & 14.5 \\
\hline & & Total & 323.6 & 85.6 & 322.6 & 70.0 \\
\hline & \multicolumn{2}{|c|}{ Leaching amount $/ \mathrm{kg} \mathrm{N} \cdot \mathrm{ha}^{-1}$} & $23.3 \mathrm{a}$ & $24.0 \mathrm{a}$ & - & - \\
\hline & \multicolumn{2}{|c|}{ Nitrate leaching rate/\% } & 7.1 & 28.0 & - & - \\
\hline \multirow{6}{*}{$\begin{array}{c}2007, \\
\text { summer maize season }\end{array}$} & \multirow{4}{*}{ Nitrate input $/ \mathrm{kg} \mathrm{N} \cdot \mathrm{ha}^{-1}$} & from fertilization & 300 & 63 & 300 & 57 \\
\hline & & from precipitation & 8.6 & 8.6 & 8.6 & 8.6 \\
\hline & & from irrigation & 4.2 & 4.2 & 4.2 & 4.2 \\
\hline & & Total & 312.8 & 75.8 & 312.8 & 69.8 \\
\hline & \multirow{2}{*}{\multicolumn{2}{|c|}{$\begin{array}{l}\text { Leaching amount } / \mathrm{kg} \mathrm{N} \cdot \mathrm{ha}^{-1} \\
\text { Nitrate leaching rate } / \%\end{array}$}} & $71.0 \mathrm{~b}$ & $41.5 c$ & $98.4 a$ & $38.6 c$ \\
\hline & & & 22.7 & 54.8 & 31.5 & 55.2 \\
\hline \multirow{6}{*}{$\begin{array}{l}\text { 2007-2008, } \\
\text { winter wheat season }\end{array}$} & \multirow{6}{*}{\multicolumn{2}{|c|}{$\begin{array}{l}\text { Leaching amount } / \mathrm{kg} \mathrm{N} \cdot \mathrm{ha}^{-1} \\
\text { Nitrate leaching rate } / \%\end{array}$}} & 300.0 & 74.0 & 300.0 & 67.0 \\
\hline & & & 4.4 & 4.4 & 4.4 & 4.4 \\
\hline & & & 21.2 & 21.2 & 8.6 & 7.5 \\
\hline & & & 325.6 & 99.6 & 313.0 & 78.9 \\
\hline & & & $74.2 \mathrm{a}$ & $30.6 b$ & $27.5 b$ & $11.0 \mathrm{c}$ \\
\hline & & & 22.8 & 30.7 & 8.8 & 13.9 \\
\hline \multicolumn{3}{|c|}{ 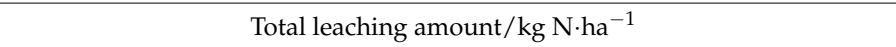 } & $172.8 \mathrm{a}$ & $101.4 \mathrm{c}$ & $131.2 \mathrm{~b}$ & $55.1 d$ \\
\hline \multicolumn{3}{|c|}{ Total Nitrate leaching rate $/ \%$} & 13.6 & 33.1 & 10.4 & 20.7 \\
\hline
\end{tabular}

Note: data in the same line with the same letter means no significant difference in means according to Duncan's multiple range test $(p<0.05)$.

During the summer maize season in 2007, serious nitrate leaching occurred under all the four management practices (Figure 6). The total leaching amounts of $\mathrm{NF}_{1} \mathrm{IR}_{1}, \mathrm{NF}_{2} \mathrm{IR}_{1}, \mathrm{NF}_{1} \mathrm{IR}_{2}$, and $\mathrm{NF}_{2} \mathrm{IR}_{2}$ were 71.0, 41.5, 98.4 and $38.6 \mathrm{~kg} \mathrm{~N} \cdot \mathrm{ha}^{-1}$, respectively (Table 3). The leaching amounts were far greater than those in 2006. Serious water leakage for excessive rainfall that occurred in this season may account for this case (Figures 2 and 3a). Under the same $\mathrm{NF}_{1}$ management practice, the nitrate leaching amount under $\mathrm{IR}_{2}$ was significantly higher than that under $\mathrm{IR}_{1}$. Comparably, under the same $\mathrm{NF}_{2}$ management, the nitrate leaching amount under $\mathrm{IR}_{2}$ and $\mathrm{IR}_{1}$ was quite similar. We concluded that under $\mathrm{NF}_{1} \mathrm{IR}_{2}$, higher soil residual nitrate that existed in the former winter season led to higher nitrate concentrations in the soil solutions (Figure 5). Therefore, the nitrate leaching amount under this management practice was the maximum in condition of high rainfalls (Figure 2). Interestingly, nitrate leaching amounts under $N_{2} I R_{1}$ and $N_{2} I_{2}$ were approximately half of those under $N_{1} I_{1}$ and $\mathrm{NF}_{1} \mathrm{IR}_{2}$. Though more water leakages were observed under $\mathrm{NF}_{2} \mathrm{IR}_{1}$ and $\mathrm{NF}_{2} \mathrm{IR}_{2}$ (Table 2), lower nitrate concentrations in the soil solutions (Figure 5) prevented higher nitrate from leaching. Besides, from the perspective of nitrate leaching rates (leaching/(fertilization + irrigation + precipitation), the same below), about $55 \%$ of nitrate input leached from the soil under the two $\mathrm{NF}_{2}$ management practices (Table 3). Consequently, timely $\mathrm{N}$ topdressing should be given more attention to increase crop growth under the $\mathrm{NF}_{2}$ management practice.

During the winter wheat season from 2007 to 2008, a slightly higher $\mathrm{N}$ input than the last summer maize season (Table 1) was adopted under $\mathrm{NF}_{2}$ for the heavy water leakage (Figure 3a). Figure 6 showed that relatively sufficient precipitation in winter led to nitrate leaching under the four combinations. The leaching amounts of $\mathrm{NF}_{1} \mathrm{IR}_{1}$ and $\mathrm{NF}_{2} \mathrm{IR}_{1}$ were 74.2 and $30.6 \mathrm{~kg} \mathrm{~N} \cdot \mathrm{ha}^{-1}$, respectively (Table 3). By contrast, those of $\mathrm{NF}_{1} \mathrm{IR}_{2}$ and $\mathrm{NF}_{2} \mathrm{IR}_{2}$ management practices were 27.5 and $11.0 \mathrm{~kg} \mathrm{~N} \cdot \mathrm{ha}{ }^{-1}$, respectively (Table 3 ). The $\mathrm{IR}_{2}$ helped to reduce both water leakage and nitrate leaching. Besides, under the same irrigation management practice, the leaching amount under $\mathrm{NF}_{2} \mathrm{IR}_{1}$ was about half of that under $\mathrm{NF}_{1} \mathrm{IR}_{1}$, and the leaching amount under $\mathrm{NF}_{2} \mathrm{IR}_{2}$ was about one-third of that under $\mathrm{NF}_{1} \mathrm{IR}_{2}$. 
The optimized $\mathrm{N}$ fertilization based on the soil testing measure could also prevent farmland nitrate from leaching effectively. Under the two effects of both $\mathrm{N}$ management and irrigation management, as much as $85.2 \%$ (= $1-10.97 / 74.21)$ of the nitrate leaching amount was prevented from contaminating the groundwater.

\section{Discussion}

After the two-year experiment, water leakages under the four management practices were compared. The obtained water leakage rate under the traditional irrigation was in line with the reported results by Zhang et al. [25]. Judging from effects of preventing water leakage, the combination of $\mathrm{NF}_{1} \mathrm{IR}_{2}$ was the best management practice. The magnitude effects followed the order of $\mathrm{NF}_{1} \mathrm{IR}_{2}>$ $\mathrm{NF}_{2} \mathrm{IR}_{2}>\mathrm{NF}_{1} \mathrm{IR}_{1}>\mathrm{NF}_{2} \mathrm{IR}_{1}$ (Table 2). It is the $\mathrm{IR}_{2}$ management practice that prevented water leakage from leaching effectively. Inversely, the $\mathrm{NF}_{2}$ management practice tended to aggravate water leakage, especially under high precipitation condition. Nutrient leaching due to frequent rainfalls and untimely topdressing under $\mathrm{NF}_{2}$ management practice (about $55 \%$ of nitrate input had leached on the basis of much less $\mathrm{N}$ input) might have resulted in poorer crop growth, and more water leakage. Guidance for timely nitrogen topdressing should be considered.

From the effects of nitrogen and irrigation management practices on nitrate concentrations at $2.0 \mathrm{~m}$ depth of the soil profile, it is easy to find that concentration gaps caused by nitrogen input are higher than those caused by irrigation (Figure 5). The amounts of nitrogen input play a great role in decreasing nitrate concentrations in the soil solutions. Reduction in the traditional nitrogen fertilization should be considered in this area. Increasing evidence has reported that nitrate leaching occurred in low-rainfall regions, episodically during extraordinarily wet periods [26,27]. In our study, the total nitrate leaching amounts under $\mathrm{NF}_{1} \mathrm{IR}_{1}$ and $\mathrm{NF}_{1} \mathrm{IR}_{2}$ were 172.8 and $131.2 \mathrm{~kg} \mathrm{~N} \cdot \mathrm{ha}{ }^{-1}$, respectively (Table 3). These results were supported by other studies in this region $[25,28]$. The continuous two-year observations in this experiment also showed us the elevated nitrate concentrations in the relatively wet summer maize and winter wheat season, especially under the traditional nitrogen fertilization management practice. Thus, soil nitrate movement to a deeper soil layer was an important pathway that caused nitrate losses in this winter wheat-summer maize rotation system.

Though heavier water leakage might be caused by nitrogen input based on soil testing, $\mathrm{NF}_{2}$ management practice is still an alternative for farmers here to effectively decrease nitrate leaching amounts and prevent groundwater contamination. Lower nitrate concentrations in the soil solution at $2.0 \mathrm{~m}$ depth prevented heavier nitrate from leaching (Table 3), especially when it is combined with the $\mathrm{IR}_{2}$ management practice. Under $\mathrm{NF}_{2} \mathrm{IR}_{2}$, the least $55.0 \mathrm{~kg} \mathrm{~N} \cdot$ ha ${ }^{-1}$ over the two years was observed. However, the effects of $\mathrm{NF}_{2}$ on crop growth should be given more attention. The $\mathrm{IR}_{2}$ had significant positive effects on both water and nitrate loss in this area.

It is reported that excessive irrigation would lead to decreased crop water use efficiency [29]. Management practices that adjust water application to crop needs also reduced nitrate leaching by a mean of $80 \%$ without a reduction in crop yield [30]. In this study, less than 10 percent irrigation water could be saved in a dry winter wheat season (from 2006 to 2007), but about 60 percent could be saved in a wet winter wheat season (from 2007 to 2008) under the $I_{2}$ management practice.

Single optimized fertilization might not work in preventing nitrate leaching in the dry winter wheat season (Table 3), but in the wet winter wheat season, a reduction of 58.8 percent nitrate leaching was acquired in the wet winter wheat season. A combination of $\mathrm{NF}_{2}$ and $\mathrm{IR}_{2}$ management practice could reduce 85.2 percent of nitrate leaching, compared with $\mathrm{NF}_{1} \mathrm{IR}_{1}$ (Table 3). Thus, optimized management practices may reduce nitrate leaching risk and could enhance environmental sustainability.

The best management practices to minimize nitrate contamination of groundwater in this area include the use of an efficient irrigation method and an optimized fertilization method. The use of an optimized irrigation method combined with soil-testing nitrogen fertilization reduced nitrate input and prevented nitrate leaching over the 2-year period. However, the economic and environmental costs 
due to applying too much groundwater might not induce farmers to embrace the new technological changes without a detailed cost-effective analysis of equipment and endeavor.

\section{Conclusions}

Water shortage and groundwater pollution due to excessive water use and nitrogen inputs are important environmental concerns in the NCP. The development of better irrigation and nitrogen fertilization management practices that minimize groundwater pollution is crucial. Field results showed that irrigation water, nitrogen fertilizer use, and nitrate leaching could be decreased substantially by applying the optimized water management in comparison with traditional methods. The optimized nitrogen fertilization management could effectively reduce nitrate concentrations of the soil solutions at $2.0 \mathrm{~m}$ depth, and then prevent nitrate leaching. However, it should be carefully managed to achieve stable grain yields. Further study is needed to find a way to maintain grain output while adopting the optimized nitrogen fertilization management practice when precipitation is too high. The optimized irrigation management practice should be considered to save groundwater resources.

Acknowledgments: This research was supported by The Key Projects in the National Science \& Technology Pillar Program during the Eleventh Five-Year Plan Period (Project No. 2006BAD17B05), Sino-US Science and Technology Cooperation Project (Project No. 2009DFA91790), and List Compilation of Priority Pollutants in Beijing Surface Water (Project No. 1541STC60334).

Author Contributions: Shufeng Chen and Wenliang Wu conceived and designed the experiments; Shufeng Chen performed the experiments; Chengchun Sun analyzed the data and wrote the paper; Wenliang $\mathrm{Wu}$ and Changhong Sun contributed reagents and materials.

Conflicts of Interest: The authors declare no conflict of interest.

\section{References}

1. Zhang, W.L.; Tian, Z.X.; Zhang, N.; Li, X.Q. Nitrate pollution of groundwater in northern China. Agric. Ecosyst. Environ. 1996, 59, 223-231. [CrossRef]

2. Liu, G.D.; Wu, W.L.; Zhang, J. Regional differentiation of non-point source pollution of agriculture-derived nitrate nitrogen in groundwater in northern China. Agric. Ecosyst. Environ. 2005, 107, 211-220. [CrossRef]

3. Karlen, D.L.; Kramer, L.A.; Logsdon, S.D. Field-scale nitrogen balances associated with long-term continuous corn production. Agron. J. 1998, 90, 644-650. [CrossRef]

4. Mahvi, A.H.; Nouri, J.; Babaei, A.A.; Nabizadeh, R. Agricultural activities impact on groundwater nitrate pollution. Int. J. Environ. Sci. Technol. 2013, 2, 41-47. [CrossRef]

5. Chen, S.; Wu, W.; Hu, K.; Li, W. The effects of land use change and irrigation water resource on nitrate contamination in shallow groundwater at county scale. Ecol. Complex. 2010, 7, 131-138. [CrossRef]

6. Hu, Y.; Moiwo, J.P.; Yang, Y.; Han, S.; Yang, Y. Agricultural water-saving and sustainable groundwater management in Shijiazhuang Irrigation District, North China Plain. J. Hydrol. 2010, 393, 219-232. [CrossRef]

7. Sun, H.; Shen, Y.; Yu, Q.; Flerchinger, G.N.; Zhang, Y.; Liu, C.; Zhang, X. Effect of precipitation change on water balance and WUE of the winter wheat summer maize rotation in the North China Plain. Agric. Water Manag. 2010, 97, 1139-1145. [CrossRef]

8. Power, J.F.; Wiese, R.; Flowerday, D. Managing nitrogen for water quality—Lessons from management systems evaluation area. J. Environ. Qual. 2000, 29, 5-66. [CrossRef]

9. Ottman, M.J.; Pope, N.V. Nitrogen fertilizer movement in the soil as influenced by nitrogen rate and timing in irrigated wheat. Soil Sci. Soc. Am. J. 2000, 64. [CrossRef]

10. Yan, L.; Zhang, Z.-D.; Zhang, J.-J.; Gao, Q.; Feng, G.-Z.; Abelrahman, A.M.; Chen, Y. Effects of improving nitrogen management on nitrogen utilization, nitrogen balance, and reactive nitrogen losses in a Mollisol with maize monoculture in Northeast China. Environ. Sci. Pollut. Res. 2016, 23, 4576-4584. [CrossRef] [PubMed]

11. Zhao, R.F.; Chen, X.P.; Zhang, F.S.; Zhang, H.L. Fertilization and nitrogen balance in a wheat maize rotation system in north China. Agron. J. 2006, 98, 938-945. [CrossRef]

12. Roth, G.W.; Fox, R.H. Soil nitrate accumulations following nitrogen-fertilized corn in Pennsylvania. J. Environ. Qual. 1990, 19, 243-248. [CrossRef] 
13. Liang, B.C.; Remillard, M.; MacKenzie, A.F. Influence of fertilizer, irrigation, and non-growing season precipitation on soil nitrate-nitrogen under corn. J. Environ. Qual. 1991, 20, 123-128. [CrossRef]

14. Paramasivam, S.; Alva, A.K. Leaching of nitrogen forms from controlled release nitrogen fertilizers 1. Commun. Soil Sci. Plant Anal. 1997, 28, 1663-1674. [CrossRef]

15. Toth, J.D.; Fox, R.H. Nitrate losses from a corn-alfalfa rotation: Lysimeter measurement of nitrate leaching. J. Environ. Qual. 1998, 27, 1027-1033. [CrossRef]

16. Sogbedji, J.M.; van Es, H.M.; Yang, C.L.; Geohring, L.D.; Magdoff, F.R. Nitrate leaching and nitrogen budget as affected by maize nitrogen rate and soil type. J. Environ. Qual. 2000, 29, 1813-1820. [CrossRef]

17. Chen, X.P. Optimization of the N Fertilizer Management of a Winter Wheat/Summer Maize Rotation System in the Northern China Plain. Ph.D. Thesis, Universität Hohenheim, Stuttgart, Germany, 2003.

18. Owens, L.B. Nitrate leaching losses from monolith lysimeters as influenced by nitrapyrin. J. Environ. Qual. 1987, 16, 34-38. [CrossRef]

19. Chen, S.F.; Wu, W.L.; Hu, K.L.; Du, Z.D.; Chu, Z.H. Characteristics of nitrate leaching in high yield farmland under different irrigation and fertilization managements in North China Plain. Trans. Chin. Soc. Agric. Eng. 2011, 27, 65-73. (In Chinese)

20. Darcy, H. Les Fontaines Publiques de la Ville de Dijon; Dalmont: Paris, France, 1856; p. 647.

21. Van Genuchten, M.T. A closed-form equation for predicting the hydraulic conductivity of unsaturated soils1. Soil Sci. Soc. Am. J. 1980, 44, 892-898. [CrossRef]

22. Kengni, L.; Vachaud, G.; Thony, J.L.; Laty, R.; Garino, B.; Casabianca, H.; Jame, P.; Viscogliosi, R. Field measurements of water and nitrogen losses under irrigated maize. J. Hydrol. 1994, 162, 23-46. [CrossRef]

23. Reynolds, W.D.; Elrick, D.E. Saturated and field-saturated water flow parameters. In Methods of Soil Analysis. Part 4. Physical Methods; Dane, J.H., Topp, G.C., Eds.; Soil Science Society of America: Madison, WI, USA, 2002; pp. 804-808.

24. Duncan, D.B. Multiple range and multiple F tests. Biometrics 1955, 11, 1-42. [CrossRef]

25. Zhang, Y.M.; Hu, C.S.; Zhang, J.B.; Chen, D.L.; Li, X.X. Nitrate leaching in an irrigated wheat-maize rotation field in the North China Plain. Pedosphere 2005, 15, 196-203.

26. Campbel, C.A.; de Jong, R.; Zentner, R.P. Effects of cropping summer fallow and fertilization nitrogen on nitrate-nitrogen by leaching on a brown chernozemic loam. Can. J. Soil Sci. 1984, 64, 64-74. [CrossRef]

27. Strong, W.M. Nitrogen fertilization of upland crops. In Nitrogen Fertilization in the Environment; Bacon, P.E., Ed.; Marcel Dekker: New York, NY, USA, 1995; pp. 129-170.

28. Zhu, A.; Zhang, J.; Zhao, B.; Cheng, Z.; Li, L. Water balance and nitrate leaching losses under intensive crop production with Ochric Aquic Cambosols in North China Plain. Environ. Int. 2005, 31, 904-912. [CrossRef] [PubMed]

29. Jin, M.; Zhang, R.; Sun, L.; Gao, Y. Temporal and spatial soil water management: A case study in the Heilonggang Region, PR China. Agric. Water Manag. 1999, 42, 173-187. [CrossRef]

30. Quemada, M.; Baranski, M.; Nobel-de Lange, M.N.J.; Vallejo, A.; Cooper, J.M. Meta-analysis of strategies to control nitrate leaching in irrigated agricultural systems and their effects on crop yield. Agric. Ecosyst. Environ. 2013, 174, 1-10. [CrossRef]

(C) 2017 by the authors. Licensee MDPI, Basel, Switzerland. This article is an open access article distributed under the terms and conditions of the Creative Commons Attribution (CC BY) license (http://creativecommons.org/licenses/by/4.0/). 